\title{
NEW NATURAL PHILOSOPHY BUILDING IN THE UNIVERSITY OF ABERDEEN
}

A NEW Natural Philosophy Building for the University of Aberdeen was opened by Sir George Thomson on May 7. From 1922 until 1930 he occupied the chair of natural philosophy, now held by Prof. R. V. Jones.

Marking the opening of the Building, and providing a reminder of the long history of Natural Philosophy in Aberdeen, was a gift by Lord Reith and Sir Noel Ashbridge. This was the certificate of merit awarded in 1860 to Lord Reith's father, the Rev. George Reith, and signed by James Clerk Maxwell, then professor of natural philosophy.

The Building (Fig. 1) is siturted on the Market Lands to the west of the High Streot of Old Aberdeen, and to the north of the Chemistry Building, opened in 1952, and the Science Library, now under construction. It accommodates the Natural Philosophy Department, formerly housed in Marischal College (at Aberdeen natural philosophy includes physics and applied mathematics). More extensive accommodation than could be provided in Marischal College, with more up-to-date facilities, has long been needed in order that the Department can play its proper part in the expansion of the annual science entry from 192 to 300 , which was required as part of the project, adopted in 1956, to expand the University from a total of 1,800 to 2,750 . It was estimated that accom. modation would be needed for that number in 1962-63 or soon after, and the Natural Philosophy Building was ready for occupation in October 1963, when the total number of graduating students reached 2,737. In 1960, in response to enquirios from the University Grants Committee, the University agreed to continue this expansion up to a total of 4,500 as a contribution to the national need for university education in the United Kingdom, and this total may now be exceeded. But the increase in the expansion from 2,500 to 4,500 will entail a project for further accommodation for natural philosophy, which is now under consideration.

The Building has been designed to accommodate 450 undergraduate students, with a first year of 300 , a second year of 100, and junior and senior honours years of 25-30 students each. In addition there will be accommodation for an academic staff of two professors, and senior lecturers, lecturers, Research Fellows, ete., to a total of 32. Facilities are also provided for about 25 postgraduate students.

The principle underlying the design is the recognition that the main functions of the Department (teaching large classes, tutoring advanced students in small groups, and research) make very different demands on many of those elements basic to design considerations. For example, one particular requirement-that of maximum possible freedom from mechanical vibration-is peculiarly a requirement of research areas. For this reason, together with general site requirements for a relatively low building, the architectural conception is that of three units linked and integrated by a firm podium.

The podium provides the main structural link between the east and west wings, with an external wall of random coarse granite and a top which is to provide circulation space. The main entrance to the building is on the south side of the podium and the three main lecture rooms are grouped round this entrance hall in such a way that the heavy student traffic to lectures is localized in this part of the Building. Lecture rooms for approximately 80 and 120 students are entered directly from the east and west sides of the entrance hall itself. A large lecture hall for 300 students is entered from the entrance hall by a short staircase under the southern part of the curved concrete shell canopy up to podium level and the main lecture room entrance. The concrete shell canopy extends over the whole of the main lecture hall, and plays a functional part in the acoustic design of the hall. The main electrical and mechanical plant serving the Building has been housed under the rake of this main lecture hall. Each lecture hall is provided with its own preparation and store rooms.

Tho whole of the north side of the podium is devoted to extensive workshops of various kinds serving the research and teaching needs of the Department. The rest of the podium area is given over to research rooms of various kinds, many of which will house delicate equipment. Every attempt has been made, by isolating the

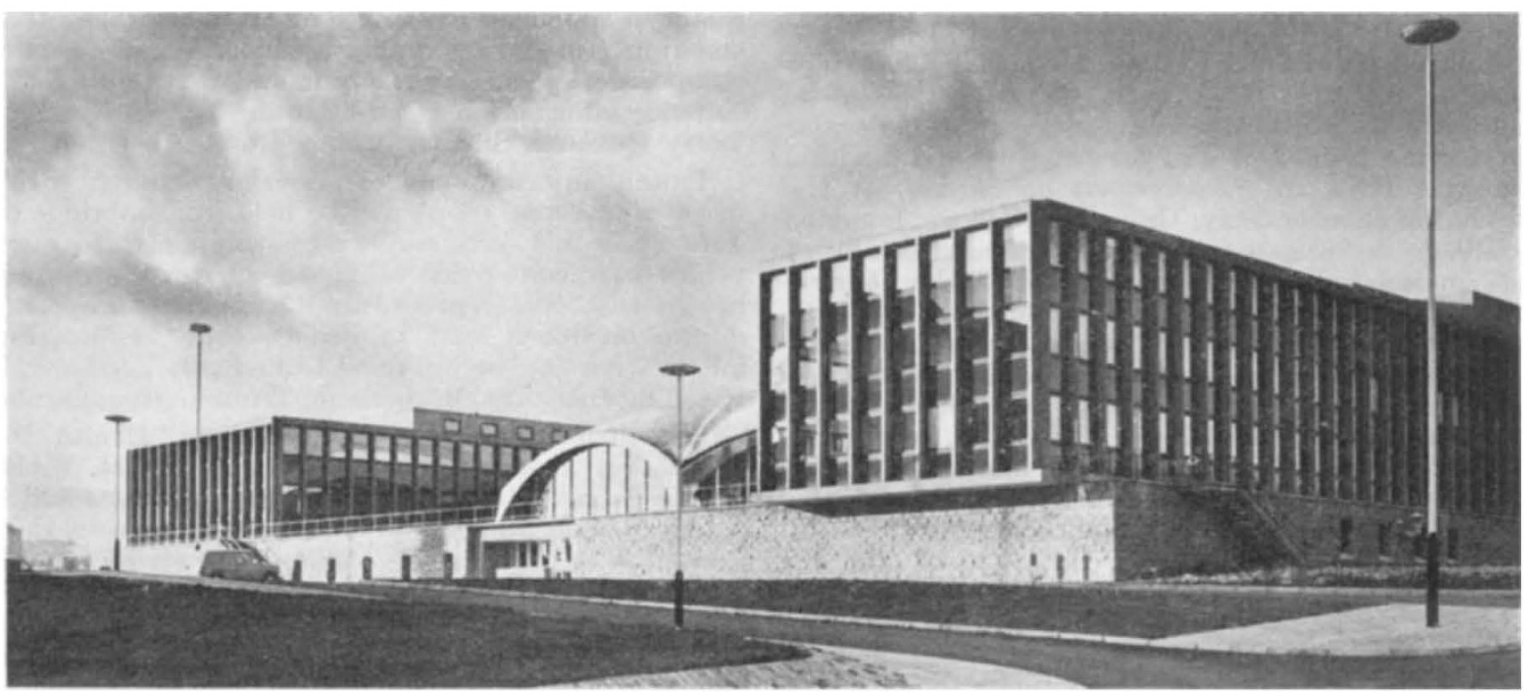

Fig. 1. New Natural Philosophy Building, University of Aberdeen 
floor pad of this area from neighbouring floor pads, and from columns supporting structures above, to ensure that this area will be mechanically quiet.

The east wing is a concrete frame structure with mullions at $5 \mathrm{ft} .4 \mathrm{in}$. intervals. It is predominantly a research and office block on three floors and has been designed so that all research rooms are on the west side of the block and all offices on the east side, thus economizing in electrical and mechanical services. Each lecturer will have a small office in which he can tutor students in groups of two or three. He may also have a research room conveniently situated opposite his office. The east wing also includes a class library, a common room, and a small lecture room which can be used for research seminars and occasional honours lectures. The flat roof of this wing has been strengthened at one end so that it can be used for experimental purposes.

The west wing houses all the teaching laboratories. The ground (podium) floor is given over to first- and second year laboratories, while the first floor houses all honours laboratories. Since the first- and second-year classes are by far the largest, this arrangement minimizes traffic on stairways and provides vibrationally the quietest conditions where most needed, that is, in the honours laboratories. The guiding principle governing the layout of the laboratories has been to prefer small laboratories of a size that can be comfortably supervised by one person. This also has the merit of providing greater flexibility in the general day-to-day use of these laboratories. In addition, each group of laboratories is provided with its own services and store rooms, together with a number of photographic dark rooms. The first floor also provides a number of tutorial rooms. where first- and secondyear tutorials in groups of 20-25 students each can be given.

The cost of the Building was approximately $£ 700,000$ provided by the University Grants Committee with a contribution from University funds.

The architect was Mr. E. D. Jefferiss Mathews of Messrs. J. Douglass Mathews and Partners, tha quantity surveyors Messrs. John Dansken and Purdie, the structural engineers Messrs. C. V. Blumfield and Partners, and the contractors Messrs. Alexander Hall and Son (Builders), Ltd., Aber. deen.

\section{AN EARLY OCCUPATIONAL HEALTH SERVICE}

$\mathrm{T}$ HE remarkable work of Samuel Greg and Dr. P. Holland in establishing an occupational health service at Quarry Bank Mill, Cheshire, in the late eighteenth century has recently been described by Dr. R. Murray, medical adviser to the Trades Union Congress (Occupational Health, 16, No. 1; January/February 1964).

Quarry Bank Mill was built as a spinning mill in 1784 by Greg, who, by 1795 , was employing his own family doctor, Dr. Holland, to provide medical care for the Company's apprentices for an annual fee of twelve guineas. Details of his work are recorded in two fully documented notebooks. The treatment was heroic and much of it consisted of purgatives - senna, calomel, rhubarb and ginger, jalap and salts. Clysters were frequently given; blisters, leeches and poultices were common. Coughs were treated with horehound and ipecac. The sick were usually given buttermilk or churn whey, though red wine, broth and even tea were sometimes prescribed. Itch was treated with sulphur, internally as well as externally.

The policy of Samuel Greg in appointing Dr. Holland as his works physician was not entirely philanthropic. He said, in answer to a correspondent, "The terms in which we take them are ... (that) we keep them one month upon trial before (being) bound ... to ascertain their prob- able healthiness". At this time the Boards of Guardians were anxious to rid themselves of the rapidly rising population of children in poorhouses, and the system of "binding them apprentice", which had served well enough for 200 years, was used to ensure a cheap supply of labour for the developing textile industry. For a variety of rcasons, many of these children were physically or mentally unfit for employment, and several employers found it worth while to employ a physician to discard those who were unlikely to make useful workers.

Nevertheless, in the case of Quarry Bank, the treatment was much more generous than elsewhere. Out of a total of 17,000 apprentices who passed through the mill, only five, apart from those under nine years, were not employed. There are several instances of children being kept for a year or more, seen regularly by Dr. Holland, and well fed in the apprentice house before being indentured. The details of the pre-employment examinations indicate the extent to which tuberculosis was a scourge of the times. Eighty per cent of the children who were labelled 'untealthy' were said to be 'delicate', to have inflammation of the eyes, enlarged glands or to be scrofulous. The fact that so many of them were ultimately able to be indentured says much for the philanthropy of Samuel Greg and the care of Dr. Holland.

\section{SEARCH FOR OIL IN AUSTRALIA}

T HE pursuit of the elusive oil-pools in Australia continues with undiminished vigour, and unfortunately the two latest reports* do little to enliven the rather depressing trend of ovents, at least from an economic point of view, recently chronicled (Nature, 201, 1080; 1964 ; and 200,$123 ; 1963$ ).

Publication No. 23 describes the exploratory borehole drilled as an off-structure stratigraphic test by the

* Commonwealth of Australia. Department of National Development. Bureau of Mineral Resources, Geology and Geophysics. Petroleum Search Subsidy Acts. Publication No. 23: Conorada Ooroonoo No. 1, Queensland, of Conorada Petroleum Corporation. Pp. 30+2 plates. Publication No. 42: O.D.N.L. Penola No. 1 Well, South Australia, of Oil Development N.L. Pp. Geophysics, 1963. )
Conorada Petroleum Corporation and known as "Conorada Ooroonoo No. 1, Queensland". The location borders the Diamantina River, about 58 miles south of Middleton, on Western Highway, western Queensland. As a stratigraphic test, this project might be judged successful, in that the log disclosed a complete section of the sedi. mentary rocks of the Great A.rtesian Basin down to and penetrating the granitic basement complex. Operations lasted barely one month and the well was abandoned as a dry hole at a total depth of $3,852 \mathrm{ft}$., the granite floor being met at $3,840 \mathrm{ft}$. Considerable problems attach to the age determination of the rocks constituting the Great Artesian Basin in this region. The possibility of finding 